\title{
Bacterial isolation and evaluation of antisepsis protocols of the operative field of bitches submitted to ovariohysterectomy
}

\author{
Isolamento bacteriano e avaliação deprotocolos de \\ antissepsia do campo operatório de cadelas submetidas \\ àovariohisterectomia
}

\author{
Sabrina Cândido Trajano* (D), Breno Bezerra Aragão ${ }^{1}$, Mauro de Araujo Penaforte Junior ${ }^{1}$ (D),

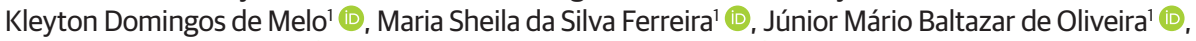 \\ Rinaldo Aparecido Mota² (1) \& Grazielle Anahy de Sousa Aleixo² (1) \\ 'Veterinarians, MSc. Programa de Pós-graduação em Medicina Veterinária - PGVET, Universidade Federal Rural de Pernambuco \\ - UFRPE, Recife, PE, Brasil \\ ${ }^{2}$ Veterinarians, DSc. Departamento de Medicina Veterinária, Universidade Federal Rural de Pernambuco - UFRPE, Recife, PE, Brasil
}

\begin{abstract}
This study evaluated the efficiency of five antisepsis protocols performed in the operative field of bitches due to the importance of preventing surgical infections in veterinary medicine. Thirty female bitches submitted to elective ovariohysterectomy $(\mathrm{OVH})$ were used and were separated into groups of eight animals. In group I, 70\% alcohol and 2\% chlorhexidine gluconate (CHG) were administered; in group II, alcoholic CHG 0.5\%; in group III, polyvinylpyrrolidone (PVPI) 10\% alcohol; in group IV, alcohol 70\% and alcoholic PVPI10\%; and in group V, alcohol, PVPI10\%, and CHG degermante 2\%. Samples were collected with sterile swabs before antisepsis, and after $3 \mathrm{~min}$, each product was used and seeded in a specific medium for colony forming unit (CFU) counts. The identification of the isolates was performed according to the morphological, dyeing, and biochemical characteristics, namely, Bacillus spp., Staphylococcus spp., Klebsiella pneumoniae, Klebsiella oxytoca, Shigella sonnei, Shigella spp., Enterobacter aerogenes, Enterobacter spp., Salmonella spp., and Escherichia coli. The results obtained allow us to conclude that the protocols with 0.5\% CHG and $2 \%$ CHG degermante were the most efficient in antisepsis that reduced 100\% of the CFU of the skin and presented better residual power until the end of the surgical procedure.
\end{abstract}

Keywords: antisepsis protocol, Cannis familiaris, elective surgery, surgical site.

\section{Resumo}

Este estudo avaliou a eficácia de cinco protocolos de antissepsia realizados no campo operatório de cadelas, devido à importância da prevenção de infecções cirúrgicas em medicina veterinária. Foram utilizadas 30 cadelas submetidas à ovariohisterectomia eletiva (OVH), divididas em grupos de oito animais. No grupo I, foram administrados álcool 70\% e gluconato de clorexidina 2\% (CHG); no grupo II, CHG alcoólico 0,5\%; no grupo III, polivinilpirrolidona (PVPI) álcool a 10\%; no grupo IV, álcool 70\% ePVPI alcoólico 10\%; e no grupo V, álcool, PVPI10\% eCHG degermante 2\%. As amostras foram coletadas com "swabs" estéreis antes da antissepsia e, após 3 minutos, cada produto foi utilizado e semeado em meio específico para contagem de unidades formadoras de colônias (UFC). A identificação dos isolados foi realizada de acordo com as características morfológicas, de tingimento e bioquímicas, a saber, Bacillus spp., Staphylococcus spp., Klebsiella pneumoniae, Klebsiella oxytoca, Shigella sonnei, Shigella spp., Enterobacter aerogenes, Enterobacter spp., Salmonella spp. e Escherichia coli. Os resultados obtidos permitem concluir que os protocolos com 0,5\% CHG e 2\% CHG degermante foram os mais eficientes na antissepsia que reduziram 100\% das UFC da pele e apresentaram melhor poder residual até o final do procedimento cirúrgico.

Palavras-chave: protocolo de antissepsia, Cannis familiaris, cirurgia eletiva, sítio cirúrgico.

\section{Introduction}

Surgical interventions include the occurrence of contamination and/or alterations causing disorders in the patient, such as pain, discomfort, and stress, in addition to increasing returns to the veterinary hospital for new treatments (Stehling et al., 2001).
How to cite: Trajano, S. C., Aragão, B. B., Penaforte Junior, M. A., Melo, K. D., Ferreira, M. S. S., Oliveira, J. M. B., Mota, R. A., \& Aleixo, G. A. S. (2018). Bacterial isolation and evaluation of antisepsis protocols of the operative field of bitches submitted to ovariohysteretomy. Brazilian Journal of Veterinary Medicine, 42, e105920. http:// dx.doi.org/10.29374/2527-2179.bjvm105920

Financial support: None.

Conflict of interests: No conflict of interests declared concerning the publication of this article.

Received: June 25, 2019.

Accepted: August 17, 2020

The study was carried out at Veterinary Hospital and the Laboratory of infectious diseases of the Departamento de Medicina Veterinária, Universidade Federal Rural de Pernambuco UFRPE, Recife, PE, Brasil.

\section{*Correspondence}

Sabrina Cândido Trajano

Departamento de Medicina Veterinária,

Universidade Federal Rural de Pernambuco - UFRPE

Rua Dom Manuel de Medeiros, s/n, Dois Irmãos

CEP 52171-900 - Recife (PE), Brasil

E-mail: sabrinacandidotrajano@gmail.com

Copyright Trajano et al. This is an Open Access article distributed under the terms of the Creative Commons Attribution Non-Commercial License which permits unrestricted non-commercial use, distribution, and reproduction in any medium provided the original work is properly cited. 
Infection of the surgical site (SSI) can affect organs or structures approached during the surgical procedure and can manifest itself between a period of 30 days to one year after surgery in cases of using implants (Poveda et al., 2003). Despite advances in hospital infection control practices in recent years, SSI is still among the leading causes of morbidity and mortality in patients in the postoperative period (Sparling et al., 2007; Singh \& Weese, 2017).

Until the middle of the19th century, surgical infections were a major obstacle to the evolution and development of surgery (Dellinger, 2003). Before the discovery of microorganisms, antisepsis, and their importance in infection, surgical procedures were performed in a bloody manner and with no prospect of patient survival being the same, as the processes were performed by so-called barber surgeons (Thorwald, 2005; Amato, 2006). Since discovery of antisepsis methods in the middle of the 19th century, surgery went through a great evolution (Dellinger, 2003).

Antisepsis of the patient's skin is one of the main measures to prevent SSI. For this, several antiseptic products have been developed over the years to prevent and reduce the risk of infection (Phillips et al., 1991). The ideal antiseptic should have a fast action, broad antimicrobial spectrum, and prolonged residual action, act in the presence of blood and secretions, does not interfere with tissue healing, in addition to being hypoallergenic, non-teratogenic, and not mutagenic (Cunha et al., 2008; Moriya \& Módena, 2008; Agência Nacional de Vigilância Sanitária, 2010). The products most used in skin antisepsis are 70\% alcohol, 10\% polyvinylpyrrolidone (PVPI), and chlorhexidine gluconate (CHG), which can be found in various concentrations and in aqueous, alcoholic, and degerming formulations (Moriya \& Módena, 2008).

It is known that the microbiota of the skin of dogs and cats is formed by two types of microorganisms, namely, the transient and resident bacteria. The transient are recent environmental microorganisms that are non-colonizing and survive for a short period on the skin, such as Gram-negative bacteria, including Escherichia coli. Resident bacteria, on the other hand, have a greater resistance and have a longer life span on the skin. They are, therefore, considered as colonizers, such as Staphylococcus spp. and Corynebacterium spp. (Murray, 1995).

To evaluate the importance of preventing surgical infections in veterinary medicine, this study aimed to highlight the efficiency of five antisepsis protocols performed on bitches undergoing ovariohysterectomy (OVH) by using 70\% alcohol solution, 2\% chlorhexidine, $0.5 \%$ alcoholic chlorhexidine, and 10\% alcoholic povidone iodine alone or in combination, so that the bacteria present on the skin of patients could be isolated and identified.

\section{Materials and methods}

This study was approved by the Ethics Committee on the Use of Animals of the referred institution, under protocol number 107/2017.

Forty healthy bitches, admitted for the elective OVH surgical procedure, were used, with no predilection for race. The animals were aged between one and six years, with body weight between seven and $13 \mathrm{~kg}$. The patients underwent a clinical and surgical risk assessment, where the following preoperative examinations were performed: blood count; biochemical with serum dosage of the enzymes alanine aminotransferase; aspartate transaminase; alkaline phosphatase; urea and creatinine; and electrocardiogram and abdominal ultrasound. The dogs - healthy and not pregnant - were subject to OVH surgery.

The bitches were separated into five groups, each comprising eight animals to perform five different antisepsis protocols. In group I, 70\% alcohol was used with 2\% CHG degermante; in group II, the alcoholic solution of CHG 0.5\% was used; in group III, 10\% alcoholic PVPI; in group IV, alcohol 70\% and alcoholic PVPI 10\%; and in group V, alcohol, followed by alcoholic PVPI 10\%, and finally CHG degermante $2 \%$ was used.

After shaving and removing the free hairs with a sterile gauze pad, a sterile swab was rubbed in a Müeller-Hinton broth solution (a moment that was considered $\mathrm{T}_{0}$ ). Thereafter, according to the protocol adopted in each group, antiseptics were applied (one at a time) to the entire area prepared with the aid of sterile gauze pads handled with sterile Colin antisepsis forceps, and another swab was rubbed 3 min after the passage of each antiseptic solution (moments $\mathrm{T}_{1^{\prime}} \mathrm{T}_{2^{\prime}}$ $\mathrm{T}_{3^{\prime}}$ and $\mathrm{T}_{4}$ depending on the protocol), thus evaluating the isolated action of each product. At the end of the surgery, another Swabian was passed to assess the reduction of the microbiota by 
the synergistic action of the solutions. All Swabians were soaked in Müeller-Hinton broth before being passed over the animal's skin.

The application of antiseptic products followed a pattern where each solution was applied once in sufficient quantity to moisten the entire operative field and, it is, then, left to act for $3 \mathrm{~min}$.

The operating room was kept with the doors closed to prevent the entry of people who were not part of the team, thus minimizing the contamination of the environment.

After collection, the tubes with Swabians were identified and sent immediately to the Laboratory of Infectious Contagious Diseases at Universidade Federal Rural de Pernambuco (UFRPE) to perform the processing.

The tubes containing the swab samples were incubated at $35-37^{\circ} \mathrm{C}$ for $24 \mathrm{~h}$ to reduce the damage caused by antiseptics to microorganisms. After incubation, the samples were diluted in 0.9\% saline until a $10^{6}$ dilution was achieved, and then the CFU quantification technique was performed by surface plating on soy tray agar (TSA), enriched with $0.02 \%$ lecithin, $5 \%$ Tween 80 , and sodium thiosulfate. For plating, $1 \mathrm{~mL}$ of each dilution was aliquoted and sown in TSA with the aid of Drigalski loops, and the same being performed in duplicate for each dilution obtained. After the inoculation of the samples, the plates were incubated at $35-37^{\circ} \mathrm{C}$ for $24 \mathrm{~h}$, and after bacterial growth, the CFU/mL count was performed (Silva et al., 2000).

The percentages of the CFU count reduction were calculated for each sample of the five protocols, using the formula given below (Osuna et al., 1990; Silva et al., 2000):

$$
\text { Immediate bacterial reduction }(\%)=\frac{\text { CFU post }- \text { trichotomy }- \text { CFU post }- \text { antisepsis } \times 100(\mathrm{~T} 1)}{\text { CFUpost }- \text { trichotomy }}
$$

Reduction of bacteria at the end of surgery $(\%)=\frac{\text { CFU post }- \text { trichotomy }- \text { CFU end of surgery } \times 100(\mathrm{~T} 2)}{\text { UFCpost }- \text { trichotomy }}$

The Swabians were also seeded on Base Agar plus 5\% sheep blood and Methylene Blue Eosin Agar (EMB LEVINE), using the streak depletion technique and subsequently incubated at $35-37^{\circ} \mathrm{C}$ for 24-48 h. The isolation of bacteria was obtained at different collection times. After this period, the colonies were read and Gram stained to determine the morphology of the bacterial agents (Stinghen et al., 2002).

After the morphotintorial evaluation of the Gram test, the bacterial isolates were inoculated in tubes containing broth Brain Heart Infusion at $35-37^{\circ} \mathrm{C}$ for $24 \mathrm{~h}$. Subsequently, biochemical tests for the identification of bacterial isolates began, where for isolates with characteristics of the genus Staphylococcus, coagulase and catalase tests were performed (Silva et al., 2017), and for the other agents, the Adolfo Lutz Institute (IAL) medium was used (Pessoa \& Silva, 1972).

After the stages of microbiological analysis of quantification, isolation, and identification of microorganisms, an antimicrobial resistance test was carried out.

The data obtained were subjected to analysis of the distribution of values (normality) using the Shapiro-Wilk test. Afterwards, the values of the UFC reduction rates obtained in the groups were compared using the Mann-Whitney nonparametric test (Sampaio, 1998). The IBM SPSS Statistics 23.0 program was used to perform statistical calculations with a significance level of $5.0 \%$.

\section{Results}

\section{Bacterial count}

The total number of samples collected from each animal varied according to the protocol adopted in each group. In groups I and IV, four samples were collected from each dog, in groups II and III, three samples, and in group V, five samples. The transoperative period varied between 16 and $21 \mathrm{~min}$, but the time required to perform antisepsis varied according to the protocol used, varying from 3-9 min. 
Bacterial growth was observed in all Swabian samples collected before antisepsis was performed $\left(\mathrm{T}_{0}\right)$; counting was possible only at -5 and -6 dilutions due to the high level of contamination.

Group I (70\% alcohol + 2\% CHG) showed intense bacterial growth in all TSA plaques before and after alcohol use, i.e., 100\% of the bitches $\left(\mathrm{T}_{1}\right)$; however, after using $\mathrm{CHG}$ degerming $2 \%\left(\mathrm{~T}_{2}\right)$, the bacterial count decreased to zero and remained until the end of the surgical procedure $\left(\mathrm{T}_{3}\right)$. In group II, the use of $0.5 \%$ alcoholic $\mathrm{CHG}\left(\mathrm{T}_{1}\right)$ resulted in a $100 \%$ bacterial reduction after antisepsis, and there was no bacterial growth until the end of the procedure $\left(\mathrm{T}_{2}\right)$.

In group III (alcoholic PVPI at 10\%), bacterial growth was observed in $25 \%$ of bitches (2/8) at $\mathrm{T}_{1}$ and $62.5 \%(5 / 8)$ at the end of the surgical procedure $\left(\mathrm{T}_{2}\right)$. In group IV (alcohol 70\% + PVPI, 10\%), bacterial growth was observed in 100\% (8/8) of the animals after the use of 70\% alcohol ( $\left.\mathrm{T}_{1}\right), 25 \%$ (2/8) after using alcoholic PVPI 10\% ( $\left.\mathrm{T}_{2}\right)$ and 50\% (4/8) at the end of the surgery $\left(\mathrm{T}_{3}\right)$. Group V (alcohol 70\% + alcoholic PVPI10\% + CHG degermante 2\%) showed bacterial growth - 100\% (8/8) at $\mathrm{T}_{1}$ and 50\% (4/8) at $\mathrm{T}_{2}$ (after using PVPI); however, there was no bacterial growth after the use of CHG degermante $2 \%\left(\mathrm{~T}_{3}\right)$ or at the end of the surgery $\left(\mathrm{T}_{4}\right)$ (Table 1$)$.

Table 1. Rate of bacterial growth of samples collected at different times.

\begin{tabular}{cccccc}
$\begin{array}{c}\text { Time of } \\
\text { collection }\end{array}$ & Group In (\%) & Group II n (\%) & Group III n (\%) & Group IV n (\%) & Group V n (\%) \\
\hline T0 & $8(100 \%)$ & $8(100 \%)$ & $8(100 \%)$ & $8(100 \%)$ & $8(100 \%)$ \\
T1 & $8(100 \%)$ & O(0\%) & $2(25 \%)$ & $8(100 \%)$ & $8(100 \%)$ \\
T2 & O(0\%) & $0(0 \%)$ & $5(62.5 \%)$ & $2(25 \%)$ & $4(50 \%)$ \\
T3 & O(0\%) & - & - & $4(50 \%)$ & $0(0 \%)$ \\
T4 & - & - & - & - & $0(0 \%)$ \\
\hline
\end{tabular}

n= number of animals; TO= berfore the antiseptic solution; Group I, T1 = alcohol 70\%, T2= CHG 2\%; T3= after surgery; Group II, T1= CHG 0,5\%, T2= after surgery; Group III, T1= PVPI 10\%, T2= after surgery; Group IV, T1= alcohol 70\%, T2= PVPI 10\%, T3= after surgery; Group V, $\mathrm{T} 1=$ alcohol 70\%, T2= PVPI 10\%, T3=CHG 2\%, T4= after surgery.

Regarding the efficiency of the antiseptic protocol, the protocols used in groups I, II, and V showed $100 \%$ bacterial reduction 3 min after using the last solution (chlorhexidine degermante $2 \%$ ) and without bacterial growth until the end of surgery. The least efficient protocols were used in groups III and IV, respectively (Table 2).

Table 2. Comparison between the reduction rates of UFC accessories in the groups.

\begin{tabular}{cc}
\hline Groups & Average rate of reduction of CFU ${ }^{1}$ \\
\hline 1 & $100.0 \pm 0.0 \mathrm{a}$ \\
2 & $100.0 \%^{\mathrm{a}}$ \\
3 & $75.5 \pm 36.3 \mathrm{~b}$ \\
4 & $68.9 \pm 52.0 \mathrm{~b}$ \\
5 & $100.0 \pm 0.0 \mathrm{a}^{*}$
\end{tabular}

${ }^{*}$ Mean and standard deviation; ${ }^{1}$ Mann-Whitney test; Different letters in the same column indicate statistical difference $(p<0.05)$ between groups.

During the surgical procedure, an acute allergic reaction was observed in $5 \%$ of the dogs (2/40) after the application of 10\% alcoholic PVPI. Within 30 days after surgery, no patient had clinical signs suggestive of SSI, such as redness, increased local temperature, pain, and secretion at the incision site.

\section{Identification of isolates}

Most of the isolates were obtained from skin swabs passed at $\mathrm{T}_{0}$, i.e., before performing antisepsis, corresponding to $63.8 \%$ (76/119). These isolates were: K. pneumoniae (9/119), K. oxytoca (5/119), S. sonnei (4/119), Shiguella spp. (1/119), E. aerogenes (16/119), Enterobacter spp. (1/119), Salmonella spp. (1/119), E. coli (2/119), coagulase-positive Staphylococcus (10/119), Bacillus spp. $\beta$-hemolytic (26/119), and Bacillus spp. non-hemolytic (4/119) (Table 3). 
Table 3. Identification and percentage of bacteria isolated in samples of skin swabs from bitches submitted to elective ovariohysterectomy $(\mathrm{OVH})$.

\begin{tabular}{cc}
\hline Bacteria Gram negativas & $\mathbf{n}(\mathbf{\%})$ \\
\hline Klebsiella pnemoniae & $9(7.5 \%)$ \\
Klebsiella oxytoca & $5(4.2 \%)$ \\
Shigella sonnei & $4(3.3 \%)$ \\
Shigella spp. & $1(0.8 \%)$ \\
Enterobacter aerogenes & $17(14.3 \%)$ \\
Enterobacter spp. & $1(0.8 \%)$ \\
Salmonela spp. & $1(0.8 \%)$ \\
Escherichia coli & $2(1.6 \%)$ \\
\hline Bacteria Gram positivas & $\mathbf{n}(\mathbf{\%})$ \\
\hline Staphylococcus coagulase + & $16(13.5 \%)$ \\
Bacillus spp. $\beta$ hemolítico & $55(46.2 \%)$ \\
Bacillus spp. não hemolítico & $8(6.7 \%)$ \\
\hline
\end{tabular}

Twenty strains (16.8\%) were isolated after the use of $70 \%$ alcohol in groups I, IV, and V: E. aerogenes (1/119), K. oxytoca (1/119), coagulase-positive Staphylococcus (2/119), Bacillus spp. $\beta$-hemolytic (13/119), and Bacillus spp. non-hemolytic (3/119). After PVPI, were identified coagulase-positive Staphylococcus (3/119), Bacillus spp. hemolytic $\beta$ (8/119), and Bacillus spp. non-hemolytic (1/119), corresponding to $10 \%(12 / 163)$. The remaining isolates were obtained from swabs passed at the end of the surgical procedure, corresponding to 8.4\% (10/163), namely, Bacillus spp. $\beta$-hemolytic (9/119) and coagulase-positive Staphylococcus (1/119). Even with the use of PVPI, it was possible to isolate bacteria of the genus Bacillus spp. ( $\beta$-hemolytic) and Staphylococcus spp. in groups III and IV and Bacillus spp. $\beta$-hemolytic in group V (Table 4).

Table 4. Bacteria isolated from cutaneous swabs in the surgical field of bitches submitted to elective ovariohysterectomy (OVH) at different times called $\mathrm{T}_{0}, \mathrm{~T}_{1}, \mathrm{~T}_{2}, \mathrm{~T}_{3^{\prime}}$ and $\mathrm{T}_{4}$.

\begin{tabular}{|c|c|c|c|c|c|c|c|c|c|c|c|c|c|c|c|c|c|c|c|c|}
\hline \multirow{2}{*}{ Bacteria } & \multicolumn{4}{|c|}{ Group I } & \multicolumn{3}{|c|}{ Group II } & \multicolumn{3}{|c|}{ Group III } & \multicolumn{4}{|c|}{ Group IV } & \multicolumn{5}{|c|}{ Group V } & \multirow{2}{*}{ Total } \\
\hline & TO & $\mathrm{T} 1$ & $\mathrm{~T} 2$ & T3 & TO & $\mathrm{T} 1$ & $\mathrm{~T} 2$ & TO & $\mathrm{T} 1$ & $\mathrm{~T} 2$ & TO & $\mathrm{T} 1$ & $\mathrm{~T} 2$ & T3 & TO & T1 & $\mathrm{T} 2$ & $\mathrm{~T} 3$ & $\mathrm{~T} 4$ & \\
\hline $\begin{array}{c}\text { Klebsiella } \\
\text { pnemoniae }\end{array}$ & $2^{*}$ & - & - & - & 2 & - & - & 2 & - & - & - & - & - & - & 3 & - & - & - & - & 9/119 \\
\hline Klebsiella oxytoca & 2 & - & - & - & 2 & - & - & - & - & - & - & 1 & - & - & - & - & - & - & - & $5 / 119$ \\
\hline Shigella sonnei & - & - & - & - & - & - & - & 1 & - & - & 2 & - & - & - & 1 & - & - & - & - & $4 / 119$ \\
\hline Shigella spp. & - & - & - & - & - & - & - & - & - & - & 1 & - & - & - & - & - & - & - & - & $1 / 119$ \\
\hline $\begin{array}{c}\text { Enterobacter } \\
\text { aerogenes }\end{array}$ & 2 & 1 & - & - & 2 & - & - & 4 & - & - & 5 & - & - & - & 3 & - & - & - & - & $17 / 119$ \\
\hline Enterobacter spp. & - & - & - & - & - & - & - & - & - & - & - & - & - & - & 1 & - & - & - & - & $1 / 119$ \\
\hline Salmonella spp. & - & - & - & - & - & - & - & 1 & - & - & - & - & - & - & - & - & - & - & - & $1 / 119$ \\
\hline $\begin{array}{c}\text { Staphylococcus } \\
\text { coagulase + }\end{array}$ & 2 & 2 & - & - & 3 & - & - & 2 & 1 & 1 & 1 & - & 2 & - & 2 & - & - & - & - & $16 / 119$ \\
\hline $\begin{array}{l}\text { Bacillus spp. } \\
\beta \text {-hemolítico }\end{array}$ & 3 & 2 & - & - & 5 & - & - & 6 & 2 & 3 & 6 & 5 & 3 & 6 & 6 & 6 & 2 & - & - & $55 / 119$ \\
\hline $\begin{array}{c}\text { Bacillus não } \\
\text { hemolítico }\end{array}$ & 2 & 2 & & - & - & - & - & - & - & - & - & 1 & 1 & - & 1 & 1 & - & - & - & $8 / 119$ \\
\hline Escherichia coli & 1 & - & - & - & 1 & - & - & - & & - & - & - & - & - & - & - & - & - & - & $2 / 119$ \\
\hline
\end{tabular}




\section{Discussion}

\section{Bacterial count}

All antisepsis methods showed some degree of efficiency in reducing the CFU count of the samples of skin swabs; however, the protocols in which the solutions of 0.5\% alcoholic CHG (group II) and 2\% alcoholic CHG (groups I and V) were the most efficient, with no CFU formation 3 min after application and at the end of the surgical procedure. This demonstrates the efficiency of this solution in surgical antisepsis, which prevented the formation of CFU and showed residual action until the end of the procedure, maintaining its antibacterial activity even in the presence of blood, as has already been reported in other studies (Moriya \& Módena, 2008; Agência Nacional de Vigilância Sanitária, 2010). In addition, the use of CHG alone for 3 min does not require the use of 70\% alcohol and/or 10\% alcoholic PVPI, reducing the time and cost of antisepsis solutions.

Although alcohol is considered the safest antiseptic due to its low toxicity and bactericidal effect (Agência Nacional de Vigilância Sanitária, 2010), its use in groups I, IV, and V was not efficient, allowing bacterial growth in all animals for 3 min after its use. The efficiency of alcohol may have been reduced due to the presence of bacterial spores that germinated when inoculated in TSA plates, since most of the isolates that grew after their use were Bacillus spp., a large spore producer. In addition, alcohol may have exerted action only on transitory bacteria, as resident bacteria are present in the deeper layers of the skin, presenting greater resistance (Bond \& Loeffler, 2012).

According to Boyce \& Prittet (2002) and Burg et al. (2007), when an emollient product is added to alcohol, its bactericidal action is improved, as its volatile capacity decreases, allowing the product to remain in contact with the skin for a longer time, despite continuing to offer no residual effect and not to destroy spores. For this, it must be used as an alcoholic preparation (PA) in association with CHG or PVPI (Moriya \& Módena, 2008; Agência Nacional de Vigilância Sanitária, 2010; Gonçalves et al., 2012). Despite the recommendations, the results obtained did not show $100 \%$ efficiency in reducing CFU when alcoholic PVPI was used.

It is known that the action of iodine is effective for 1-2 min and has a residual effect of 2-4 h; however, this was not observed in this study, even though the time required for the action of the product was respected as recommended (Agência Nacional de Vigilância Sanitária, 2010). The low efficiency of iodine can be explained by its inactivation in the presence of blood. PVPI can also be inactivated in the presence of inorganic compounds such as alcohol; however, in this study, alcohol did not interfere with the action of PVPI because in group III alcohol was not used before PVPI and even then, it showed low efficiency (Cunha et al., 2008; Moriya \& Módena, 2008; Agência Nacional de Vigilância Sanitária, 2010).

An immediate allergic reaction to PVPI was observed in two dogs in this study. The same occurred in a study carried out by Osuna et al. (1990), where they mentioned that $50 \%$ of the areas prepared with this solution had an acute allergy. PVPI causes less skin irritation than iodine; however, it causes more contact dermatitis than other antiseptic solutions such as CHG. A major negative factor of iodine present in PVPI is its affinity for organic matter, and it also reduces its efficiency Due to this, new alternatives should be sought (Agência Nacional de Vigilância Sanitária, 2010).

Rodrigues (1997) suggested the use of CHG as an alternative to replacing PVPI in patients allergic to iodine, which occurred in two dogs in the current study. CHG is poorly absorbed by intact skin, and if percutaneous absorption occurs, it becomes insignificant. However, CHG has no indication for use in antisepsis in some areas such as the ear and eye region due to its ototoxic activity, which may cause eye damage (Larson, 1988). In addition, it can also slow down the healing process and cause flaking in the tissues (Agência Nacional de Vigilância Sanitária, 2010).

The results showed that there was no significant difference between the use of $0.5 \%$ alcoholic CHG and 2\% dehydrating CHG, as both reduced the UFC count by 100\% 3 min after use and maintained residual action until the end of the surgical procedure. This result was similar to other studies where CHG was used in the antisepsis of dogs and cats (Osuna et al., 1990; Silva et al., 2000; Marchi et al., 2018). Alcoholic CHG 0.5\% is easier and more practical to apply to the skin, with no need to remove the excess product, as it evaporates, leaving the skin dry, unlike what happens with CHG degermante, where it is necessary to remove the excess product.

As in this study, CHG has also been shown to have superior antiseptic activity when compared to PVPI. In a study by Darouiche et al. (2010), the group that received antisepsis with CHG 0.5\% 
had less infection than the group where PVPI was used. Other authors have reported the use of chlorhexidine to combat outbreaks of $S$. aureus, including those that have methicillin resistance in intensive care units in human hospitals through daily baths in adults and newborn children (Christensen et al., 2001; El Helali et al., 2005; Sandri et al., 2006; Cunha et al., 2008). While Nogueira et al. (1999) reported similar antimicrobial activity between CHG and PVPI suggesting that both are ideal for surgical antisepsis of the abdominal operative field of cats with an action time of five min; however, the authors do not mention product concentrations.

Some criteria must be followed for the choice of antiseptics, such as the spectrum of antimicrobial activity, speed of action, residual power, low toxicity, good performance in the presence of organic matter, and not interfering in the wound healing and repair process (Osuna et al., 1990; Phillips et al., 1991; Schulz, 2014). Stubbs et al. (1996) indicated that CHG is the antiseptic of choice, as it fulfills the desired qualifications for an antiseptic solution. In this study, dogs that used CHG degermante $2 \%$ and alcoholic CHG 0.5\% in the antiseptic protocol did not present an acute allergic reaction, had good healing of the surgical wound and, in addition, had excellent bactericidal action and residual effect, being these antiseptic solutions that best fit the characteristics recommended for an ideal antiseptic.

\section{Identification of isolates}

Regarding the isolates, Gram-positive bacteria were the most frequent (66.4\%); however, the majority were of the genus Bacillus spp. (52.9\%), which are environmental bacteria that have no clinical importance. The other $13.5 \%$ were isolated from the Staphylococcus genus, all of which showed a positive reaction in the coagulase and catalase tests. Similar studies identified a greater number and also identified a greater number of Gram-positive bacteria on the skin of dogs and cats (Ishii et al., 2011; Murta et al., 2015).

Coagulase-positive Staphylococcus species can behave opportunistically (Frank et al., 2003; Morris et al., 2006), which can cause serious infections in the postoperative period of these animals (Oliveira et al., 2006; DeLeo \& Chambers, 2009). Studies show the transmission of opportunistic pathogens such as coagulase-positive Staphylococcus (SCP) between humans and dogs, including species that have multidrug resistance, such as $S$. aureus and S. pseudointermedius, the first being considered an anthropozoonosis, where transmission probably occurs in humans (Tomlin et al., 1999). This makes the animals in this research in which Staphylococcus isolates become a risk group for SSI.

Regarding the action of antiseptic solutions on bacterial isolates, alcoholic CHG 0.5\% and CHG degermanent $2 \%$ eliminated $100 \%$ of the isolates, which is different from what was described in a study carried out by Monteiro et al. (2001), in which they reported bacterial growth in $20 \%$ of the dogs after antisepsis with CHG degermante $2 \%$. Alcohol 70\% before the use of CHG degermante $2 \%$ in group I, and alcoholic PVPI 10\% in group IV did not interfere with their action.

The use of alcohol in groups I, IV and V (at time T1) had a varied action when comparing Gram-positive and Gram-negative bacteria, where it was observed that in relation to Gram-positive bacteria, the germicidal action was not significant because the number of bacterial strains isolated before the use of $70 \%$ alcohol had a reduction of only $21 \%$ after the use of the product (5/23). Regarding Gram-negatives, there was a significant rate of colony reduction of 91.3\% (21/23). Alcohol is characterized by having a fast action against Gram-positive and Gam-negative bacteria; however, in this study, it did not show fast action and did not show efficiency against Grampositive bacteria, as reported in the literature. To improve its antiseptic capacity, the literature recommends using alcohol in PA with CHG or PVPI, as occurred in group II (Boyce \& Prittet, 2002; Moriya \& Módena, 2008; Gonçalves et al., 2012).

The $0.5 \%$ alcoholic CHG PA used in group II bitches' antisepsis eliminated $100 \%$ of Gram-negative and Gram-positive bacteria, preventing bacterial growth until the end of the surgical procedure. Strains of SCP and Bacillus spp. $\beta$-hemolytics that were resistant to 70\% alcohol and 10\% alcoholic PVPI were sensitive to 0.5\% alcoholic CHG, in agreement with Stubbs et al. (1996), who reported that CHG has an action against Staphylococcus genus bacteria and is therefore used to control outbreaks of S.aureus, including those that are resistant to methicillin in intensive care units in human hospitals, through daily baths and intranasal use in adults and newborn children (Christensen et al., 2001; El Helali et al., 2005; Sandri et al., 2006; Cunha et al., 2008). 
The use of alcohol and PVPI was not sufficient to eliminate bacterial flora in groups III, IV, and $\mathrm{V}$, in which it was possible to isolate Gram-positive bacteria after their use. The $10 \%$ alcoholic PVPI solution was also used in group V together with the $2 \%$ CHG degerming agent. After its use, the remaining microorganisms from alcohol and PVPI were eliminated, and the 2\% CHG degerming solution that prevented bacterial growth until the end of the surgical procedure was more efficient than alcoholic PVPI 10\%.

Even with the use of PVPI, it was possible to isolate bacteria such as Bacillus spp. $\beta$-hemolytic and coagulase-positive Staphylococcus in groups III and IV and Bacillus spp. $\beta$-hemolytic in group V, which is a producer of spores, according to Sagripanti \& Bonifacino (1996) and McDonnell \& Russell (1999). The spores of bacteria of the genus Bacillus are resistant to different types of antiseptics, including PVPI.

Bacterial growth at the end of surgery in the groups where the PVPI solution was used as a part of the antiseptic protocol (groups III, IV and V) demonstrated that this solution did not present a good residual action, since the surgical procedure lasted between 16 and 21 min (short duration) and bacterial growth of Staphylococcus spp. and Bacillus spp. Considering that there was bacterial growth in a short-term surgical procedure, its use against long-term surgery antisepsis is contraindicated. In a study by Monteiro et al. (2001), the growth of S. aureus and Bacillus spp. was observed in $40 \%$ of the animals after antisepsis with PVPI and growth of Bacillus spp. in $20 \%$ of dogs using $2 \%$ CHG degerming. They associated the growth of Bacillus spp. to the fact that CHG has no action against spores.

In this research, when alcoholic PVPI 10\% was associated with CHG degermante $2 \%$, there was no bacterial growth until the end of the surgery; however, we believe that it was the action of $\mathrm{CHG}$ degermante $2 \%$ that did not allow bacterial proliferation and promoted residual action.

\section{Conclusion}

It was concluded that the protocols where 0.5\% alcoholic CHG and 2\% deodorant were used showed the best antiseptic activity when applied to the skin of bitches that were submitted to elective OVH presented 100\% effectiveness in eliminating CFU until the end of the surgical procedure. Due to its practical application on the skin, owing to its bactericidal and residual action,

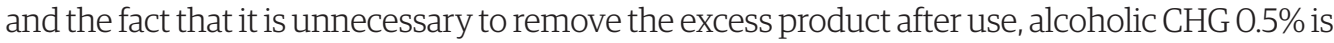
recommended as the antiseptic of choice to perform skin antisepsis in dogs.

\section{References}

Agência Nacional de Vigilância Sanitária - ANVISA. (2010). Segurança do paciente: higienização das mãos (pp. 9-89). Brasília.

Amato, A. C. M. (2006). História da cirurgia. In I. N. Morais (Ed.), Tratado de clínica cirúrgica (pp. 3-17). São Paulo: Roca.

Bond, R., \& Loeffler, A. (2012). What's happened to Staphylococcus intermedius? Taxonomic revision and emergence of multi-drug resistance. The Journal of Small Animal Practice, 53(3), 147-154. http://dx.doi.org/10.1111/j.17485827.2011.01165.x. PMid:22251285.

Boyce J.M. \& Prittet D. (2002). Guideline for Hand Hygiene in Health-Care Settings. Recommendations of the Healthcare Infection Control Practices Advisory Committee and the HICPAC/SHEA/APIC/IDSA Hand Hygiene Task Force. Society for Healthcare Epidemiology of America/Association for Professionals in Infection Control/ Infectious Diseases Society of America. MMWR. Recommendations and Reports, 51, 1-45. PMid:12418624.

Burg, G., Portela, O., Paraginski, G. L., Souza, V., Silveira, D. D., \& Hörner, R. (2007). Estudo da eficácia de um novo produto à base de álcool gel utilizado na anti-sepsia em um serviço de nefrologia. Veterinary Medicine, 40(2), 236-242. http://dx.doi.org/10.11606/issn.2176-7262.v40i2p236-242.

Christensen, A., Scheel, O., Urwitz, K., \& Bergh, K. (2001). Outbreak of methicillinresistant Staphylococcus aureus in a Norwegian hospital. Scandinavian Journal of Infectious Diseases, 33(9), 663-669. http://dx.doi. org/10.1080/00365540110026944. PMid:11669223.

Cunha, M. L., Procianoy, R. S., Franceschini, D. T., De Oliveira, L. L., \& Cunha, M. L. (2008). Effect of the first bath with chlorheridine on skin colonization with Staphylococcus aureus in normal healthy term newborns. Scandinavian Journal of Infectious Diseases, 40(8), 615-620. http://dx.doi.org/10.1080/00365540801932447. PMid:18979599.

Dellinger, E. P. (2003). Infecções cirúrgicas e escolha dos antimicrobianos. In C. M. Townsend (Ed.), Tratado de cirurgia (pp. 182-200). Rio de Janeiro: Guanabara Koogan. 
Darouiche, R. O., Mural Junior, M. J., Itani, K. M., Otterson, M. F., Webb, A. L., Carrich, M. M., Miller, H. J., Awad, S. S., Crosby, C. T., Mosier, M. C., Alsharif, A., \& Berger, D. H. (2010). Álcool clorexidina versus iodopovidona para antissepsia no local cirúrgico. The New England Journal of Medicine,362, 18-26. http://dx.doi.org/10.1056/ NEJMoa0810988. PMid:20054046.

DeLeo, F., \& Chambers, H. F. (2009). Reemergence of antibiotic-resistant Staphylococcus aureus in the genomics era. The Journal of Clinical Investigation, 119(9), 2464-2474. http://dx.doi.org/10.1172/JCI38226. PMid:19729844.

El Helali, N., Carbonne, A., Naas, T., Kerneis, S., Fresco, O., Giovangrandi, Y., Fortineau, N., Nordmann, P., \& Astagneau, P. (2005). Nosocomial outbreak of staphylococcal scalded skin syndrome in neonates: epidemiological investigation and control. The Journal of Hospital Infection, 61(2), 130-138. http://dx.doi. org/10.1016/j.jhin.2005.02.013. PMid:16009455.

Frank, L. A., Kania, S. A., Hnilica, K. A., Wilkes, R. P., \& Bemis, D. A. (2003). Isolation of Staphylococcus schleiferi from dogs with pyoderma. Journal of the American Veterinary Medical Association, 222(4), 451-454. http:// dx.doi.org/10.2460/javma.2003.222.451. PMid:12597417.

Gonçalves, K. J., Graziano, K. U., \& Kawagoe, J. Y. (2012). Revisão sistemática sobre antissepsia cirúrgica das mãos com preparação alcoólica em comparação aos produtos tradicionais. Revista da Escola de Enfermagem da USP, 46, 1484-1493. http://dx.doi.org/10.1590/S0080-62342012000600028.

Ishii, J. B., Freitas, J. C., \& Arias, M. V. B. (2011). Resistência de bactérias isoladas de cães e gatos no hospital veterinário da Universidade Estadual de Londrina (2008-2009). Pesquisa Veterinária Brasileira, 31(6), 533-537. http://dx.doi.org/10.1590/S0100-736X2011000600013.

Larson, E. (1988). Guideline for use of topical antimicrobial agents. American Journal of Infection Control, 16(6), 253-266. http://dx.doi.org/10.1016/50196-6553(88)80005-1. PMid:2849888.

Marchi, M. N. A., Sargi, L. F., Martins, R. R., Luz, P. E., Tanaka, Y., Pereira, U. P., \& Pereira, P. M. (2018). Skin antisepsis protocols for the collection of blood from donor dgos. Ciência Rural, 48(5), 1-4. http://dx.doi. org/10.1590/0103-8478cr20170505.

McDonnell, G., \& Russell, A. D. (1999). Antiseptics and Disinfectants: Activity, action, and resistance. Clinical Microbiology Reviews, 12(1), 147-179. http://dx.doi.org/10.1128/CMR.12.1.147. PMid:9880479.

Monteiro, V. L. C., Coelho, M. C. O. C., Mota, R. A., Carrazzoni, P. G., Tenório Filho, F., Lima, E. T., \& Monteiro, F. G. C. (2001). Anti-sepsia de pele de cães utilizando-se clorexidina a 2\%, povidine a 10\% e álcool iodado a $5 \%$. Ciência Animal, 11, 7-12.

Moriya, T., \& Módena, J. L. P. (2008). Assepsia e antissepsia: técnicas de esterilização. Medicina, 41, 265-267.

Morris, D. O., Rook, K. A., Shofer, F. S., \& Rankin, S. C. (2006). Screening of Staphylococcus aureus, Staphylococcus intermedius and Staphylococcus schleiferi isolates obtained from small companion animals for antimicrobial resisteance: a retrospective review of 749 isolates (2003-2004). Veterinary Dermatology, 17(5), 332-337. http:// dx.doi.org/10.1111/j.1365-3164.2006.00536.x. PMid:16961819.

Murta, A. R., Abreu Junior, N. A., Oliveira, L. S., Reis, E. C. C., Valente, F. L., Gonçalves, G. P., Eleotério, R. B., \& Borges, A. P. B. (2015). Perfil epidemiológico e análise microbiológica da infeccão de sítio cirúrgico em pacientes humanos e animais de companhia. Pesquisa Veterinária Brasileira, 35(7), 652-658. http://dx.doi.org/10.1590/ s0100-736X2015000700009.

Nogueira, C. C. C., Franco, R. M. F., Vasconcellos, C. H. C., Ferreira, T., \& Nascimento Junior, A. (1999). Avaliação de três anti-sépticos na redução da microbiota cutânea abdominal em gatos. Revista Brasileira de Ciência Veterinária, 6(1), 9-13. http://dx.doi.org/10.4322/rbcv.2015.124.

Oliveira, L. C., Brilhante, R. S. N., Cunha, A. M. S., \& Carvalho, C. B. M. (2006). Profile of microorganisms isolated from dogs with associated media and extern otitis. Arquivo Brasileiro de Medicina Veterinária e Zootecnia, 58, 1009-1017. http://dx.doi.org/10.1590/S0102-09352006000600006.

Osuna, D. J., DeYoung, D. J., \& Walker, R. L. (1990). Comparison of three skin preparation techniques in the dog Part 1: experimental trial. Veterinary Surgery, 19(1), 14-19. http://dx.doi.org/10.1111/j.1532-950X.1990.tb01136.x. PMid:2301156.

Pessoa, G. V. A., \& Silva, E. A. M. (1972). Meios de Rugai e lisina-motilidade combinados em um só tubo para identificação presuntiva de enterobactérias. Revista do Instituto Adolfo Lutz, 32, 97-100.

Phillips, M. F., Vasseur, P. B., \& Gregory, C. R. (1991). Chlorhexidine diacetate versus povidone-iodine for preoperative preparation of the skin: a prospective randomized comparison in dogs and cats. Journal of the American Animal Hospital Association, 27, 105-108.

Poveda, V. B., Galvão, C. M., \& Hayashida, M. (2003). Análise dos fatores de risco relacionados à incidência de infecção do sítio cirúrgico e gastro-cirúrgicas. Revista da Escola de Enfermagem da US P., 37(1), 81-89. http:// dx.doi.org/10.1590/S0080-62342003000100010.

Rodrigues, E. A. C. (1997). Infecções hospitalares prevenção e controle (1. ed.). São Paulo: Sarvier.

Sagripanti, J. L., \& Bonifacino, A. (1996). Comparative sporicidal effects of liquid chemical agents. Applied and Environmental Microbiology, 62(2), 545-551. http://dx.doi.org/10.1128/AEM.62.2.545-551.1996. PMid:8593054.

Sampaio, I. B. M. (1998). Estatística aplicada à experimentação animal. Belo Horizonte: Fundação de Ensino e Pesquisa em Medicina Veterinária e Zootecnia. 
Sandri, A. M., Dalarosa, M. G., Alcântara, L. R., Elias, L. S., \& Zavascki, A. P. (2006). Reduction in incidence of nosocomial methicillin-resistant Staphylococcus aureus (MRSA) infection in an intensive care unit: role of treatment with mupirocin ointment and chlorhexidine baths for nasal carriers of MRSA. Infection Control and Hospital Epidemiology, 27(2), 185-187. http://dx.doi.org/10.1086/500625. PMid:16465636.

Schulz, K. S. (2014). Princípios de assepsia cirúrgica. In T. W. Fossum (Ed.), Cirurgia de pequenos animais (4. ed., p. 1-10). Rio de Janeiro: Mosby.

Silva, D. A. R., Costa, M. M., Vargas, A. C., Alievi, M. M., Schossler, J. E. W., \& Silva, T. R. (2000). O gluconato de clorexidina ou o álcool-iodo-álcool na anti-sepsia de campos operatórios em cães. Ciência Rural,30(3), 431-437. http://dx.doi.org/10.1590/S0103-84782000000300010.

Silva, N., Junqueira, V. C. A., \& Silveira, N. F. A. (2017). Manual de métodos de análise microbiológica de alimentos e água (5. ed.). São Paulo: Varela.

Singh, A., \& Weese, J. S. (2017). Wound infections and antimicrobial use. In K. M. Tobias, \& S. A. Johnston (Eds.), Veterinary surgery: small animal (2nd ed., pp. 530-549). St. Louis: Elsevier.

Sparling, K. W., Ryckman, F. C., Schoettker, P. J., Byczkowski, T. L., Helpling, A., Mandel, K., Panchanathan, A., \& Kotagal, U. R. (2007). Financial impact of failing to prevent surgical site infections. Quality Management in Health Care, 16(3), 219-225. http://dx.doi.org/10.1097/01.QMH.0000281058.99929.ea. PMid:17627217.

Stehling, M. C., Cunha, A. F., \& Maria, E. (2001). Prevenção e controle de infecção em serviço de medicina veterinária, In M. A. Martins (Ed.), Manual de infecção hospitalar, epidemiologia, prevenção e controle (2. ed., p. 915-927). Belo Horizonte: Medice.

Stinghen, A. E. M., Albini, C. A., \& Souza, H. A. P. H. M. (2002). Coloração de Gram: como fazer, interpretar e padronizar. Curitiba: Microscience.

Stubbs, W. P., Bellah, J. R., Vermaas-Hekman, D., Purich, B., \& Kubilis, P. S. (1996). Chlorhexidine gluconate versus chloroxylenol for preoperative skin preparation in dogs. Veterinary Surgery, 25(6), 487-494. http://dx.doi. org/10.1111/j.1532-950X.1996.tb01448.x. PMid:8923728.

Thorwald, J. (2005). O século dos cirurgiões: conforme os documentos do meu avô (1. ed.). São Paulo: Hartmann.

Tomlin, J., Pead, M. J., Lloyd, D. H., Howell, S., Hartmann, F., Jackson, H. A., \& Muir, P. (1999). Methicillin-resitant Staphylococcus aureus infections in 11 dogs. The Veterinary Record, 144(3), 60-64. PMid:10070689. 